\title{
Supremacy of the EU Charter in National Courts in Purely Domestic Cases
}

VB verfassungsblog.de/the-eu-as-a-community-of-human-rights/

András Jakab Mi 27 Mrz 2013

Mi $27 \mathrm{Mrz}$

2013

The European Union is not just a community based on common interests but is also a community of values. These values are peace, democracy, the rule of law and human rights. If the EU does not want to lose its credibility, it has a duty to defend all of these values to the greatest extent possible, at least within Europe, and especially within the European Union. The different options of how to enforce these values do not exclude, but rather reinforce each other.

Most of them depend on political discretion (isolation of the political party concerned within its European party family, art. $7 \mathrm{TEU}$, treaty infringement procedures initiated by the Commission), which makes the use of these methods unreliable as guarantees of the abovementioned values. European politicians might (and actually often do) behave in an opportunistic manner, they are interested in smoothening the conflicts or even in pretending that there are no conflicts. European politicians might have a tendency to turn a blind eye against such problems when faced with a major crisis within the EU which seems to them to be of more importance than issues of constitutionalism in one of the Member States. We should of course expect European politicians to believe in the values of constitutionalism, but liberty is based on distrust towards politicians. A mechanism which leaves the enforcement of constitutionalism in the hands of politicians is a useful, but unreliable mechanism. Reliable mechanisms are judicially guaranteed mechanisms, where those affected can enforce these values.

The most promising way to conceptualise the values of European constitutionalism in a judicially enforceable manner is to widen the application of the EU Charter of Fundamental Rights. There are four ways in which the role of the Charter can be viewed:

(1) If interpreted restrictively (as the dominant view of German academic writing does), then the Charter only applies in extreme cases of breach of the Charter.

(2) If interpreted literally, art. 51 of the Charter defines the scope through the application of EU law: the Charter only applies if EU law is applicable, so basically a collateral application of the Charter (confirmed by C-617/10, Åkerberg Fransson on 26.02.2013).

(3) If interpreted widely, the Charter also applies outside of the scope of EU law. The reason for such an interpretation is that union citizenship must entail a last guarantee of fundamental rights for cases of systemic failure in a Member State. This "Reverse Solange" approach has been advanced by Armin von Bogdandy and his colleagues and it has been widely discussed on Verfassungsblog.

(4) If interpreted even more widely, union citizenship does not only entail a guarantee for the total failure of national mechanisms, but it also ensures the general applicability of the Charter in all domestic cases. I am going to argue for this last solution.

If we bind the applicability of the Charter to the applicability of EU law as is suggested by the restrictive interpretations (1) and (2), then we basically deny or at least very strongly limit the value community nature of the EU. If we enable the Charter beyond this only in extreme cases as proposed in (3), then we are building a value community (which is definitely better than the former two solutions). If we, however, aim for a fully fledged value community which benefits all its citizens equally, then the Charter as such should gain full applicability in every case, even in purely domestic cases in domestic courts and even if there is no systemic failure of fundamental rights protection on a domestic level.

This means that via the supremacy of EU law (more precisely here: that of the Charter) decentralised judicial review will be introduced all around Europe. The European Union could become in this way a "community of 
fundamental rights" where nobody can be left behind (by the way, the idea of excluding a Member State because of fundamental rights violations is an appalling and unacceptable denial of a European moral community: the citizens of the excluded country would be left behind to suffer, whereas the rest of Europe would save itself). This would be especially important in cases where, in a sacrilegious manner, violations of fundamental rights are entrenched in constitutions and where constitutional courts have been filled up with party soldiers who do not care about constitutional arguments. Ordinary courts have the advantage that there are many of them in every country, the personnel is consequently difficult to exchange along party political lines, and even one single ordinary judge is able to cry for help in the form of a preliminary reference to the CJEU.

Sooner or later the CJEU is going to receive a preliminary reference from a small countryside court in one of the EU Member States (be it a large or a small Member State), so it will be given the opportunity to make, without exaggeration, one of the biggest leading cases of modern constitutionalism. A European Marbury v. Madison is yet to come, which will transform the Charter into a real Charter for all European citizens, into a Charter which guarantees their freedoms even when domestic forums fail.

The CJEU will have to face this challenge and it should not shy away from the task. Leading cases often seem impossible (or even doctrinally doubtful) at the time in which they were made, but if they confirm the general value system of society and if they help the judiciary to enhance these values, then they later become obvious and unquestionable (e.g. the direct effect of directives was considered by many to be a contra legem interpretation of the EEC Treaty... until it became a permanent feature of the case law of the ECJ). If we do not want to give art. 51 of the Charter a meaning which deprives Union citizens of their fundamental rights, then the provision should rather be seen as the determination of a minimal, and not a maximal, scope for the Charter.

The ECtHR is unable to take this step, as in many countries the ECHR does not have direct applicability and supremacy. But the ECtHR can deliver the moral authority, i.e. if the CJEU wants to make a stronger case then it is advisable for the CJEU to fully rely on ECtHR case law wherever it is possible (cf. art. 52 para 3, art. 53).

In general, the EU should rely on the authority of the Council of Europe, including the Venice Commission, as otherwise (economic or other) sanctions might appear to be part of a political game or a money saving measure, especially if enforcement is in the hands of the Commission. A further difficulty is that for such a mechanism to exist, a modification of the founding treaties would be necessary. As I have argued in a Jean Monnet Working Paper on the Full Parliamentarisation of the EU without Changing the Treaties, such modifications are difficult for politicians to accept as they result in them losing their discretionary powers. A re-interpretation of existing treaty provisions is more realistic in such cases. Thus a Copenhagen Commission as proposed by Jan-Werner Müller is both difficult to introduce and (in case I am wrong and it will be introduced) not advisable to apply.

Every society is held together by certain values, which are at least rhetorically unquestionable. In the Middle Ages, it was Christianity, heretics had to face the consequences of breaching religious taboos. After WWII, in Western Europe, and since the end of communism in the whole of Europe, these integrating values have been the secular values of constitutionalism. There were and there will be heretic attempts to question these values, but if we want to believe that European integration has a chance, then we have to stop these attempts before it becomes too late. If it can happen in one EU Member State, then it can also happen in another one, and the European edifice which is built on these values will surprisingly quickly fall apart.

\section{LICENSED UNDER CC BY NC ND}

SUGGESTED CITATION Jakab, András: Supremacy of the EU Charter in National Courts in Purely Domestic Cases, VerfBlog, 2013/3/27, http://verfassungsblog.de/the-eu-as-a-community-of-human-rights/. 